\title{
Penentuan titik potong skor sindroma metabolik remaja dan penilaian validitas diagnostik parameter antropometri: analisis Riskesdas 2013
}

Determination of cutoff points for metabolic syndrome scores in Indonesian adolescents and assessment of the diagnostic validity of anthropometric parameters

\section{Zahra Anggita Pratiwi ${ }^{1}$, Mubasysyir Hasanbasri ${ }^{1}$, Emy Huriyati ${ }^{2}$}

${ }^{1}$ Departemen Biostatistik, Epidemiologi, dan Kesehatan Populasi, Fakultas Kedokteran Universitas Gadjah Mada

${ }^{2}$ Departemen Gizi dan Kesehatan, Fakultas Kedokteran Universitas Gadjah Mada

\begin{abstract}
Background: The risk of death caused by non-communicable diseases is related to metabolic syndrome. Metabolic syndrome not only occurs in adults, but also occurs in adolescents. The problem of metabolic syndrome in adolescents shows the importance of early detection and management. Early detection of metabolic syndrome in adolescents can be done through non-invasive approaches such as anthropometric measurements. However, the definition of metabolic syndrome has so far not reached an agreement. Objective: This study aims 1) To know the intersection points of adolescent metabolic syndrome; 2) To know the best anthropometry parameters for detecting metabolic syndrome in adolescents. Method: This study used cross sectional design, using Riskesdas 2013 survey data. The sample size of this study was 3273 adolescents aged 15-24 years. The analysis using receiver operating characteristic curve (ROC) indicated the accuracy of the score to diagnose metabolic syndrome, supported by area under the curve $(A U C)$ results. The best parameters were seen from the largest AUC values, taking into account the sensitivity and specificity values. Results: The metabolic syndrome scores in general for Indonesian adolescents $=2.21$ (sensitivity $=83 \%$, specificity $=84 \%$ ). Specific cut off point for women $=2.02$ (sensitivity $=84 \%$, specificity $=85 \%$ ), and for males $=2.40$ (sensitivity $=86 \%$, specificity $=82 \%$ ). The best anthropometric parameters for detecting metabolic syndrome in adolescents are abdominal circumference $(A U C=0.77$; sensitivity $=71 \%$, specificity $=67 \%)$. Conclusion: Abdominal circumference has the best validity and can be used for early detection of the risk of metabolic syndrome in adolescents.
\end{abstract}

KEY WORDS: anthropometric parameter; cut off point; Indonesian adolescent; metabolic syndrome score

\begin{abstract}
ABSTRAK
Latar belakang: Risiko kematian yang disebabkan oleh penyakit tidak menular berkaitan dengan sindroma metabolik. Sindroma metabolik tidak hanya terjadi pada orang dewasa, tetapi juga terjadi pada remaja. Permasalahan sindroma metabolik pada remaja menunjukkan pentingnya deteksi dan manajemen dini. Upaya deteksi dini sindroma metabolik pada remaja dapat dilakukan melalui pendekatan non-invasive seperti melakukan pengukuran antropometri. Namun, definisi sindroma metabolik sampai saat ini masih belum mencapai kesepakatan. Tujuan: Penelitian ini bertujuan untuk 1) Mengetahui titik potong skor sindroma metabolik remaja; 2) Mengetahui parameter antropometri terbaik untuk mendeteksi sindroma metabolik pada remaja. Metode: Penelitian dengan desain cross sectional menggunakan data survei Riskesdas 2013. Besar sampel penelitian sebesar 3.273 remaja usia 1524 tahun. Analisis menggunakan kurva receiver operating characteristic (ROC) dalam mengindikasikan keakuratan skor untuk mendiagnosis sindroma metabolik, didukung dengan hasil area under the curve (AUC). Parameter terbaik dilihat dari nilai AUC terbesar dengan mempertimbangkan nilai sensitivitas dan spesifisitas. Hasil: Titik potong skor sindroma metabolik secara umum untuk remaja Indonesia $=2,21$ ( sensitivitas $=83 \%$, spesifitas $=84 \%$ ). Titik potong spesifik untuk perempuan $=2,02($ sensitivitas $=84 \%$, spesifisitas $=85 \%$ ) dan untuk laki-laki $=2,40($ sensitivitas $=86 \%$, spesifisitas $=82 \%)$. Parameter antropometri terbaik untuk mendeteksi sindroma metabolik pada remaja adalah lingkar perut $(\mathrm{AUC}=0,77$; sensitivitas $=71 \%$, spesifisitas $=67 \%$ ). Simpulan: Lingkar perut memiliki validitas yang paling baik dan dapat digunakan untuk deteksi dini risiko sindroma metabolik pada remaja.
\end{abstract}

KATA KUNCI: parameter antropometri; titik potong; remaja Indonesia; skor sindroma metabolik

Korespondensi: Zahra Anggita Pratiwi, Departemen Biostatistik, Epidemiologi, dan Kesehatan Populasi, Fakultas Kedokteran Universitas Gadjah Mada, Jl. Farmako Sekip Utara, Yogyakarta 55281, e-mail: zahraanggita91@gmail.com 


\section{PENDAHULUAN}

Sindroma metabolik merupakan kumpulan gejala kelainan metabolik tubuh yang mencakup dislipidemia (peningkatan kadar trigliserida dan penurunan high density lipoprotein/HDL), hiperglikemia, hipertensi, dan obesitas sentral (1). Sindroma metabolik bukan merupakan penyakit, tetapi lebih menggambarkan kumpulan faktor risiko metabolik yang berhubungan langsung dengan penyakit tidak menular, terutama penyakit kardiovaskuler arterosklerotik (1). Penderita sindroma metabolik berisiko mengalami penyakit kardiovaskular dan komplikasi diabetes mellitus. Sindroma metabolik berkaitan dengan mortalitas dan morbiditas penyakit kardiovaskular (2).

Penelitian menemukan sindroma metabolik tidak hanya terjadi pada kelompok usia dewasa, tetapi dapat pula mulai terjadi pada usia muda. Data menunjukkan prevalensi sindroma metabolik pada remaja Amerika mencapai 12,7\% (3) dan 13\% pada remaja Korea (4). Prevalensi sindroma metabolik pada usia lebih dari atau sama dengan 15 tahun di Indonesia sebesar 12,5\% (5). Kondisi pubertas merupakan sumber potensial terjadinya sindroma metabolik pada remaja karena terjadi perubahan regulasi hormon dan distribusi lemak yang dapat menyebabkan pertambahan berat badan (6).

Beberapa ahli telah merumuskan definisi sindroma metabolik. Saat ini terdapat tiga definisi sindroma metabolik yang telah dirumuskan dan sering digunakan pada penelitian yaitu definisi World Health Organization (WHO); National Cholesterol Education Program Expert Panel on Detection, Evaluation and Treatment of High Blood Cholesterol In Adults Treatment Panel III (NCEP ATP-III); dan International Diabetes Federeation (IDF). Ketiga definisi tersebut memiliki komponen utama sama dengan penentuan kriteria yang berbeda (7). Belum adanya kesepakatan dalam mendefinisikan sindroma metabolik memungkinkan penemuan yang berbeda pada penelitian epidemiologi dan rendahnya prevalensi pada beberapa populasi. Alasan itu yang mendorong American Diabetes Association dan European Association for the Study of Diabetes merekomendasikan untuk menggunakan continuous value of metabolic syndrome atau skor sindroma metabolik (SSM) $(8,9)$.

Skor sindroma metabolik adalah penilaian semua komponen sindroma metabolik dengan menggunakan perhitungan z-score. Penggunaan skor dalam mendeteksi sindroma metabolik membutuhkan nilai titik potong sebagai dasar diagnosis. Nilai titik potong didefiniskan sebagai nilai antara normal dan abnormal atau nilai batas hasil uji positif dan negatif (10). Di beberapa negara sudah memiliki titik potong skor sindroma metabolik seperti di India, Iran, dan Brazil (11-13). Indonesia belum memiliki nilai titik potong skor sindroma metabolik khususnya pada remaja sehingga diperlukan penelitian terkait penentuan nilai titik potong skor sindroma metabolik di Indonesia.

Permasalahan sindroma metabolik pada remaja menunjukkan pentingnya dilakukan deteksi dan manajemen dini (6). Diagnosis sindroma metabolik dilakukan dengan tes darah (invansive) untuk mengetahui kondisi metabolik tubuh. Beberapa penelitian menemukan deteksi dini sindroma metabolik dapat dilakukan melalui pendekatan non-invasive yang murah dan sederhana seperti pengukuran antropometri. Hasil penelitian sebelumnya memaparkan bahwa pengukuran tekanan darah dan indeks massa tubuh (IMT) dapat dilakukan untuk memprediksi sindroma metabolik tahap awal ketika tes darah tidak dapat dilakukan (14). Hal tersebut didukung dengan penelitian lain yang menyatakan bahwa pengukuran antropometri yang teratur, penting untuk mendeteksi risiko sindroma metabolik pada kelompok eksekutif di Jakarta (15).

Pengukuran antropometri menggambarkan pengukuran massa tubuh, ukuran, bentuk, dan tingkat kegemukan. Pengukuran antropometri yang sering dilakukan untuk memperkirakan komposisi tubuh adalah indeks massa tubuh (IMT), lingkar perut (LP), dan rasio lingkar perut terhadap tinggi badan (LP/TB) (2). Penting adanya penelitian diagnostik terkait parameter antropometri mana yang lebih sensitif dan spesifik dalam mendeteksi risiko sindroma metabolik pada remaja. Tujuan penelitian ini adalah untuk mengetahui nilai titik potong skor sindroma metabolik pada remaja dan mengetahui parameter antropometri yang paling baik dalam mendeteksi sindroma metabolik pada remaja.

\section{BAHAN DAN METODE}

Penelitian kuantitatif ini menggunakan data sekunder Riset Kesehatan Dasar (Riskesdas) 2013. 
Riskesdas merupakan survei skala nasional berkala yang dilakukan oleh Badan Penelitian dan Pengembangan Kesehatan Kementerian RI untuk memantau indikator kesehatan seluruh wilayah Indonesia. Penelitian Riskesdas 2013 dilakukan di 33 provinsi, 497 kabupaten/ kota yang mencakup 12.000 blok sensus terpilih. Pemeriksaan biomedis yang dilakukan mewakili tingkat nasional yang merupakan sub-sample provinsi (1000 blok sensus). Pengumpulan data (wawancara, pengukuran, pemeriksaan, pengambilan spesimen darah, data entry, dan validasi) dilakukan pada bulan Mei sampai Juni 2013 (16).

Unit analisis penelitian ini adalah remaja berusia 15 sampai 24 tahun yang mengikuti survei Riskesdas 2013 dan melakukan pemeriksaan sampel darah (kadar glukosa darah puasa, kolesterol HDL, dan trigliserida), serta mengukur berat badan, tinggi badan, lingkar perut, dan tekanan darah. Kriteria eksklusi penelitian ini adalah subjek dengan data yang tidak lengkap pada variabel yang diteliti. Alur pemilihan subjek penelitian tercantum pada Gambar 1.

Penentuan titik potong skor sindroma metabolik menggunakan analisis kurva Receiver Operating Characteristic (ROC) dan Area Under The Curve (AUC). Area di bawah kurva ROC digunakan untuk menilai keakuratan suatu diagnosis. Semakin luas AUC, maka menunjukkan tes atau uji terbaik. Dalam menentukan titik potong skor sindroma metabolik, membutuhkan pembanding standar. Penelitian ini menggunakan baku standar kriteria sindroma metabolik NCEP ATP-III modifikasi untuk remaja. Definisi sindroma metabolik berdasarkan NCEP ATP-III adalah seseorang menderita
Jumlah remaja usia 15 - 24 tahun (unit analisis) yang mengikuti survei Riskesdas $2013=\mathbf{3 5 6 8}$ orang

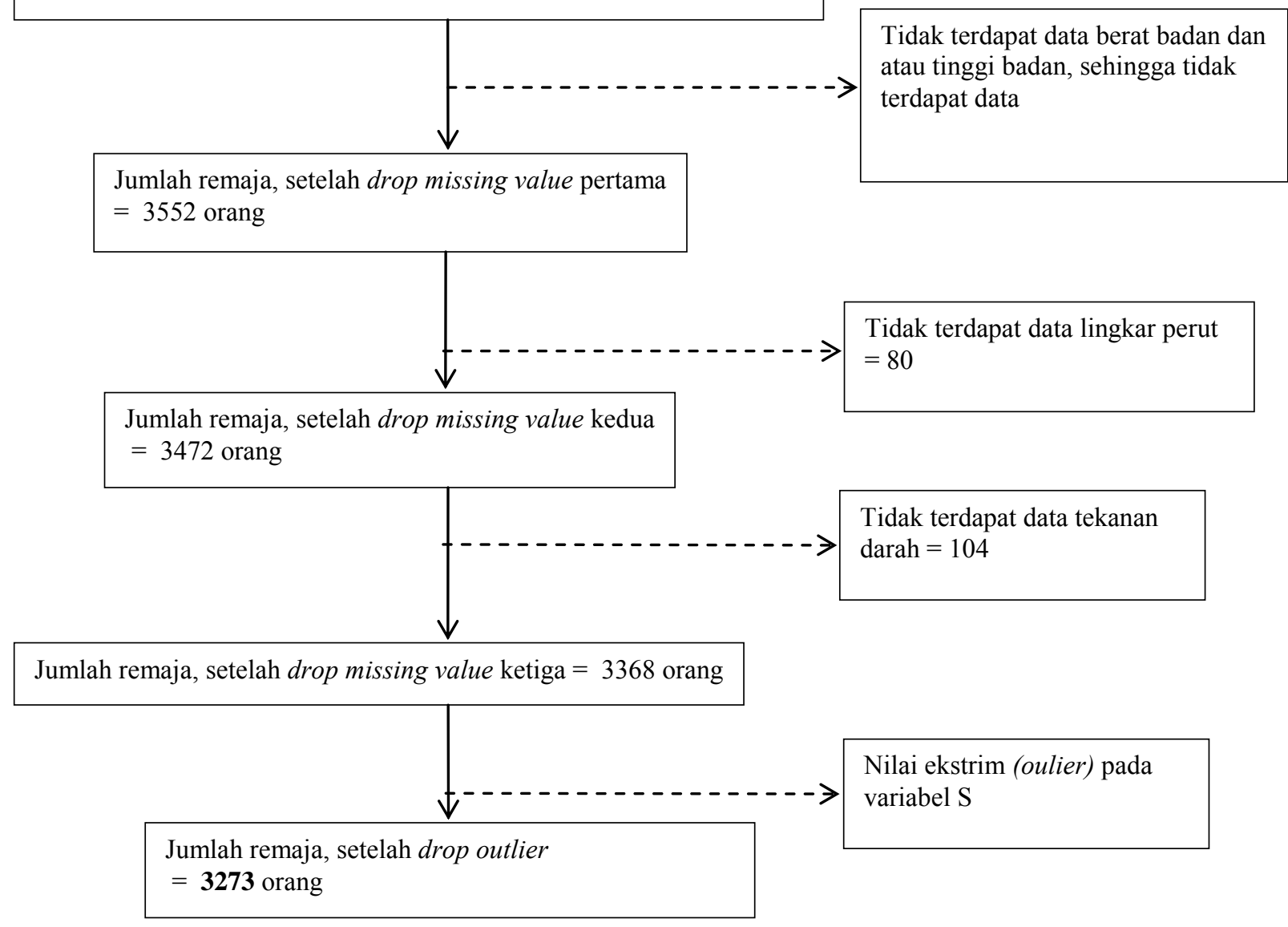

Gambar 1. Alur pemilihan subjek penelitian 
sindroma metabolik jika menderita minimal tiga dari lima kriteria. Lima kriteria tersebut adalah 1) Lingkar perut $\geq 90^{\text {th }}$ persentil; 2) $\mathrm{HDL} \leq 40 \mathrm{mg} / \mathrm{dL} ; 3$ ) Trigliserida $\geq 110 \mathrm{mg} / \mathrm{dL}$; 4) Tekanan darah $\geq 90^{\text {th }}$ persentil; dan 5) Glukosa darah puasa (GDP) $\geq 110 \mathrm{mg} / \mathrm{dL}$ (17). Alasan kriteria NCEP ATP-III digunakan sebagai standar baku karena lebih sederhana dan reliable untuk digunakan dibandingkan definisi WHO, European Group for the Study of Insulin Resistance (EGIR), dan International Diabetes Federation (IDF) $(18,19)$.

Perhitungan skor sindroma metabolik (SSM) dilakukan untuk semua komponen sindrom metabolik (lingkar perut, tekanan darah, trigliserida, HDL, dan glukosa darah puasa) dengan menggunakan $z$-score yang mengacu pada penelitian sebelumnya (20). Skor sindroma metabolik (SSM) merupakan total $z$-score semua komponen sindroma metabolik. Sistem skoring tekanan darah menggunakan mean arterial pressure $(\mathrm{MAP})=[$ tekanan darah sistolik-tekanan darah diastolik/3)+tekanan darah diastolik] $(13,21)$. Rumus perhitungan z-score untuk lingkar perut, MAP, trigliserida, dan glukosa darah puasa:

$$
\text { Z-score }=\frac{\text { Nilai individu-mean }}{\text { standar deviasi }}
$$

Perhitungan z-score HDL, digunakan rumus berikut:

$$
\text { Z-score }=\frac{\text { Mean-nilai individu }}{\text { standar deviasi }}
$$

Interpretasi skor sindroma metabolik (SSM) adalah semakin rendah skor yang dimiliki seseorang, maka semakin baik kondisi metabolime $(20,22)$.

Penilaian validitas diagnostik parameter antropometri untuk memprediksi skor sindroma metabolik berupa nilai sensitivitas dan spesifisitas setiap parameter antropometri yaitu IMT, lingkar perut, dan rasio lingkar perut-tinggi badan. Analisis yang dilakukan adalah analisis kurva ROC yang didukung dengan hasil AUC. AUC dibagi menjadi tiga kategori yaitu, 1) Akurasi rendah jika 0,5<AUC $\leq 0,7 ; 2$ ) Akurasi sedang jika 0,7 $<$ AUC $\leq 0,9$; 3) Akurasi tinggi jika $0,9<\mathrm{AUC} \leq 1,0$. Parameter terbaik adalah yang memiliki nilai AUC terbesar (13).

\section{HASIL}

\section{Deskripsi subjek penelitian}

Subjek penelitian merupakan remaja Indonesia berusia 15-24 tahun yang merupakan subjek penelitian Riskesdas 2013. Rerata usia subjek adalah $19 \pm 2,87$ tahun. Total sampel penelitian ini sebanyak 3.273 subjek, laki-laki $(43,63 \%)$ dan perempuan $(56,37 \%)$. Sebagian besar subjek penelitian memiliki status gizi normal. Sebanyak 6,90\% subjek penelitian ini memiliki kadar GDP yang tidak normal. Subjek yang memiliki kadar HDL kolesterol rendah (tidak normal) sebanyak 43,29\%. Kadar trigliserida subjek yang tidak normal sebanyak $21,51 \%$ serta subjek yang mengalami obesitas abdominal sebanyak 5,04\% dan hipertensi sebanyak 21,08\% (Tabel 1.).

Tabel 1. Karakteristik subjek penelitian

\begin{tabular}{lcc}
\hline Variabel & $\begin{array}{c}\text { Frekuensi } \\
\text { (n=3.273) }\end{array}$ & $\begin{array}{c}\text { Persentase } \\
\text { (\%) }\end{array}$ \\
\hline Jenis kelamin & & \\
Laki-laki & 1.428 & 43,63 \\
Perempuan & 1.845 & 56,37 \\
Kategori usia & & \\
$\quad$ Remaja awal & 1.546 & 47,78 \\
Remaja akhir & 1.709 & 52,22 \\
Status Gizi & & \\
Kurus & 517 & 15,80 \\
Normal & 2.425 & 74,09 \\
Overweight & 190 & 5,81 \\
Obesitas & 141 & 4,31 \\
Glukosa darah puasa & & \\
Normal & 3.047 & 93,10 \\
Tidak normal & 226 & 6,90 \\
HDL & & \\
Normal & 1.856 & 55,71 \\
Tidak normal & 1.417 & 43,29 \\
Trigliserida & & \\
Normal & & \\
Tidak normal & 2.569 & 78,49 \\
Lingkar pinggang & 704 & 21,51 \\
Obesitas abdominal & & \\
Tidak obesitas abdominal & 3.108 & 94,96 \\
Tekanan darah & & \\
Hipertensi & 690 & 21,08 \\
Tidak hipertensi & 2.583 & 78,92 \\
\hline$\quad$ & &
\end{tabular}


Tabel 2. Distribusi ukuran komponen sindroma metabolik berdasarkan jenis kelamin

\begin{tabular}{|c|c|c|c|}
\hline \multirow{2}{*}{$\begin{array}{c}\text { Komponen sindroma } \\
\text { metabolik }\end{array}$} & \multicolumn{2}{|c|}{ Rerata } & \multirow{2}{*}{$\mathbf{p}^{1}$} \\
\hline & Laki-laki & Perempuan & \\
\hline Lingkar perut $(\mathrm{cm})$ & $70,35 \pm 7,61$ & $71,04 \pm 8,82$ & 0,0192 \\
\hline Tekanan sistolik (mmHg) & $115,93 \pm 11,44$ & $109,42 \pm 10,82$ & $<0,0001$ \\
\hline Tekanan diastolik (mmHg) & $74,08 \pm 8,92$ & $75,67 \pm 8,54$ & $<0,0001$ \\
\hline $\mathrm{GDP}^{2}(\mathrm{mg} / \mathrm{dL})$ & $95,95 \pm 9,16$ & $94,51 \pm 9,51$ & $<0,0001$ \\
\hline $\mathrm{HDL}^{3}(\mathrm{mg} / \mathrm{dL})$ & $45,09 \pm 9,78$ & $51,50 \pm 11,77$ & $<0,0001$ \\
\hline Trigliserida (mg/dL) & $96,09 \pm 42,34$ & $86,95 \pm 41,05$ & $<0,0001$ \\
\hline
\end{tabular}

${ }^{1}$ uji Chi-Square, signifikan secara statistik $(\mathrm{p}<0,05) ;{ }^{2} \mathrm{GDP}=$ glukosa darah puasa; ${ }^{3} \mathrm{HDL}=$ high density lipoprotein

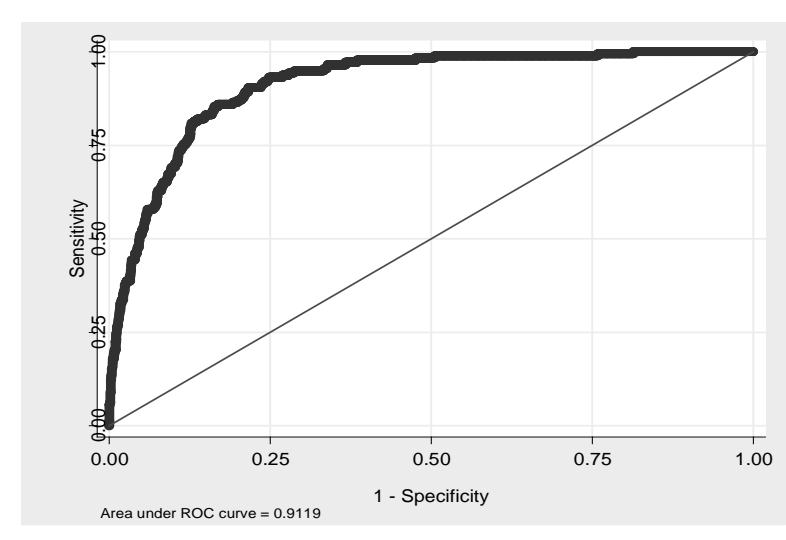

Gambar 2. Nilai AUC dengan kurva ROC

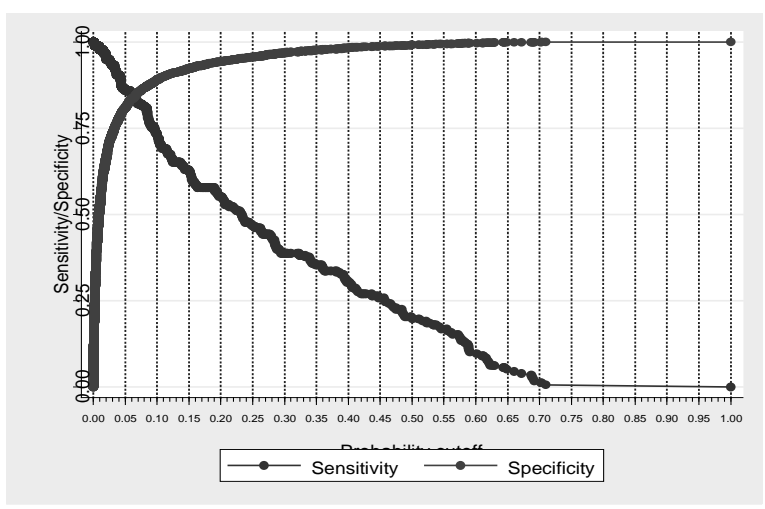

Gambar 3. Kurva ROC dalam penentuan titik potong SSM

Remaja perempuan memiliki rerata lingkar perut lebih tinggi dibandingkan remaja laki-laki dan signifikan secara statistik $(p=0,0192 ; p>0,05)$. Sementara itu, tekanan sistolik dan diastolik, kadar glukosa darah puasa (GDP), HDL, dan trigliserida remaja laki-laki lebih tinggi daripada remaja perempuan. Penelitian ini menemukan perempuan memiliki kadar kolesterol HDL lebih tinggi daripada laki-laki dan bermakna secara statistik (Tabel 2).

\section{Penentuan titik potong skor sindroma metabolik}

Penentuan titik potong secara statistik melalui dua tahap yaitu pertama, dengan melakukan analisis regresi logistik; kedua, dengan membuat grafik sensitivitasspesifisitas untuk menentukan titik potong. Pada hasil analisis regresi logistik didapatkan nilai $\mathrm{p}<0,0001(95 \%$ CI:0,72-0,88), artinya SSM secara statistik berhubungan dengan kriteria sindroma metabolik NCEP ATP-III.

Kurva ROC yang menggambarkan nilai AUC disajikan pada Gambar 2. Terlihat nilai AUC SSM terhadap sindroma metabolik adalah sebesar 0,9119 yang menunjukkan bahwa SSM memiliki akurasi yang tinggi secara statistik untuk mendiagnosis sindroma metabolik pada remaja. Langkah selanjutnya adalah membuat grafik sensitivitas dan spesifisitas untuk menentukan nilai titik potong. Titik potong probabilitas SSM diketahui dari kurva perpotongan antara sensitivitas dan spesifisitas pada Gambar 3.

Nilai titik potong optimal SSM yang tergambarkan dari titik potong probabilitas adalah 0,065 (sensitivitas $=83,1 \%$; spesifisitas $=84,2 \%$ ). Hal ini menunjukkan probabilitas $6,5 \%$ merupakan nilai batas optimal untuk mendeteksi dan membedakan antara remaja yang menderita sindroma metabolik dan orang sehat. Titik potong probabilitas SSM terhadap SM (NCEP ATP III) tersebut bertepatan dengan skor sindroma metabolik sebesar 2,21. Dapat disimpulkan secara umum remaja usia 15-24 tahun di Indonesia yang memiliki SSM 


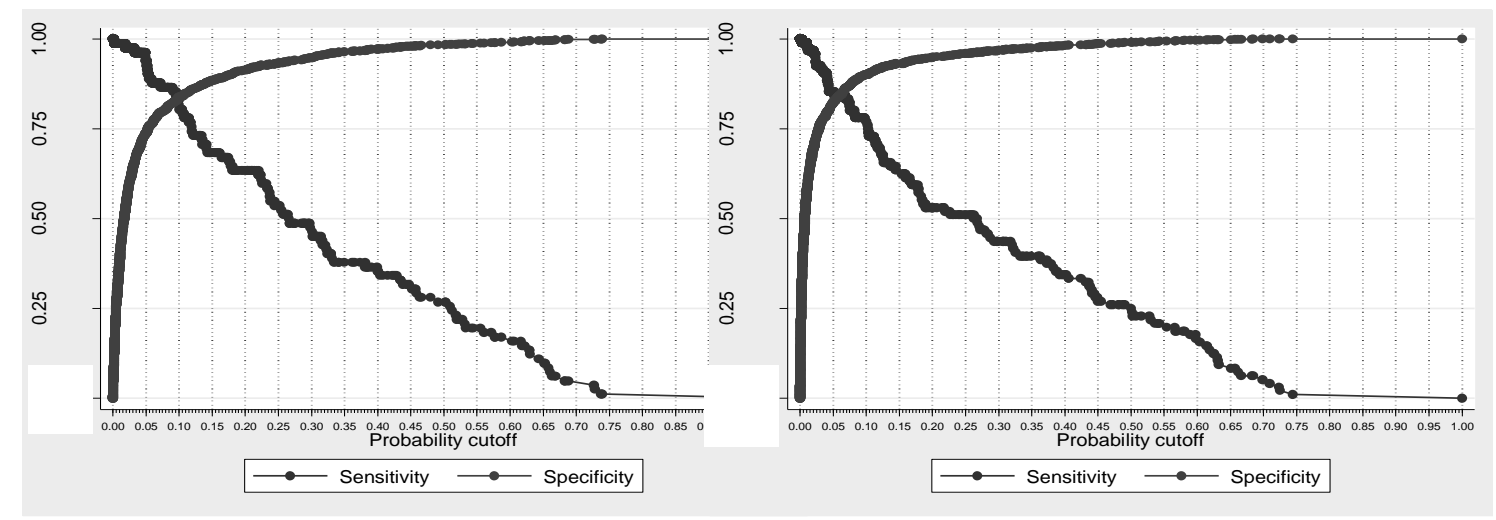

Keterangan: A: Kurva ROC untuk laki-laki; B: Kurva ROC untuk perempuan

Gambar 4. Kurva ROC penentuan titik potong berdasarkan jenis kelamin

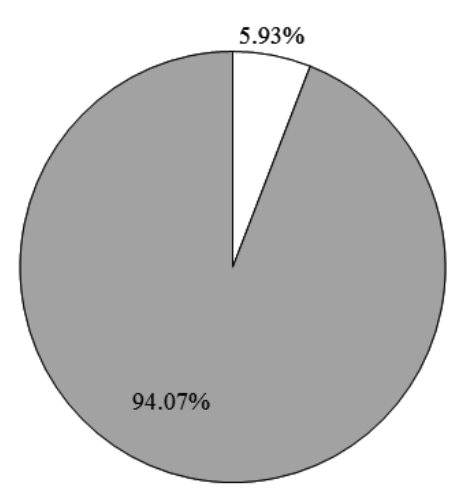

A

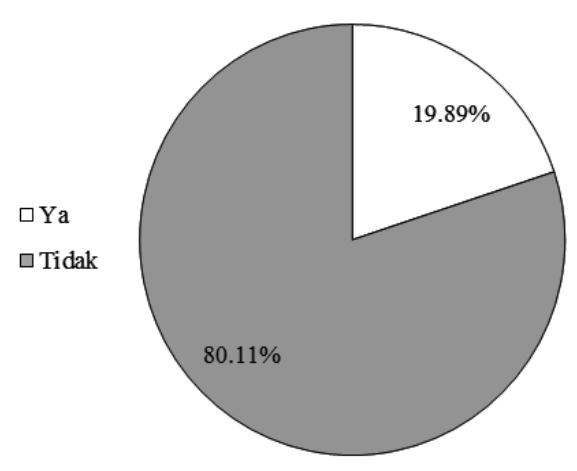

B

Keterangan: A: Prevalensi sindroma metabolik berdasarkan kriteria NCEP ATP-III; B: Prevalensi sindroma metabolik dengan skoring (SSM)

Gambar 5. Prevalensi sindroma metabolik remaja

Tabel 3. Perbandingan titik potong SSM berdasarkan jenis kelamin

\begin{tabular}{lcccccc}
\hline & n & AUC & 95\% Conf. Interval & Titik potong & Sensitivitas & Spesifisitas \\
\hline Laki-laki & 1428 & 0,92 & $0,76-1,90$ & 2,40 & $86 \%$ & $82 \%$ \\
Perempuan & 1845 & 0,92 & $0,76-1,07$ & 2,02 & $84 \%$ & $85 \%$ \\
Umum & 3273 & 0,91 & $0,79-1,01$ & 2,21 & $83 \%$ & $84 \%$ \\
\hline
\end{tabular}

di atas 2,21 didiagnosis menderita sindroma metabolik. Titik potong SSM dibedakan berdasarkan jenis kelamin karena perempuan dan laki-laki memiliki perbedaan kecenderungan untuk menderita SM. Kurva ROC dalam penentuan titik potong SSM berdasarkan jenis kelamin ditampilkan pada Gambar 4.

Lebih lanjut, Tabel 3. menunjukkan perbandingan titik potong SSM pada laki-laki dan perempuan, serta titik potong SSM secara umum. Berdasarkan analisis, titik potong SSM laki-laki lebih tinggi dibandingkan titik potong perempuan.

Hasil penelitian ini menunjukkan prevalensi sindroma metabolik dengan metode skoring atau yang dikenal dengan SSM pada remaja usia 15-24 tahun sebesar 19,89\%. Di sisi lain, prevalensi sindroma metabolik berdasarkan kriteria NCEP ATP-III lebih rendah dibandingkan dengan prevalensi menggunakan metode skoring yaitu sebesar 5,93\% (Gambar 5.). 


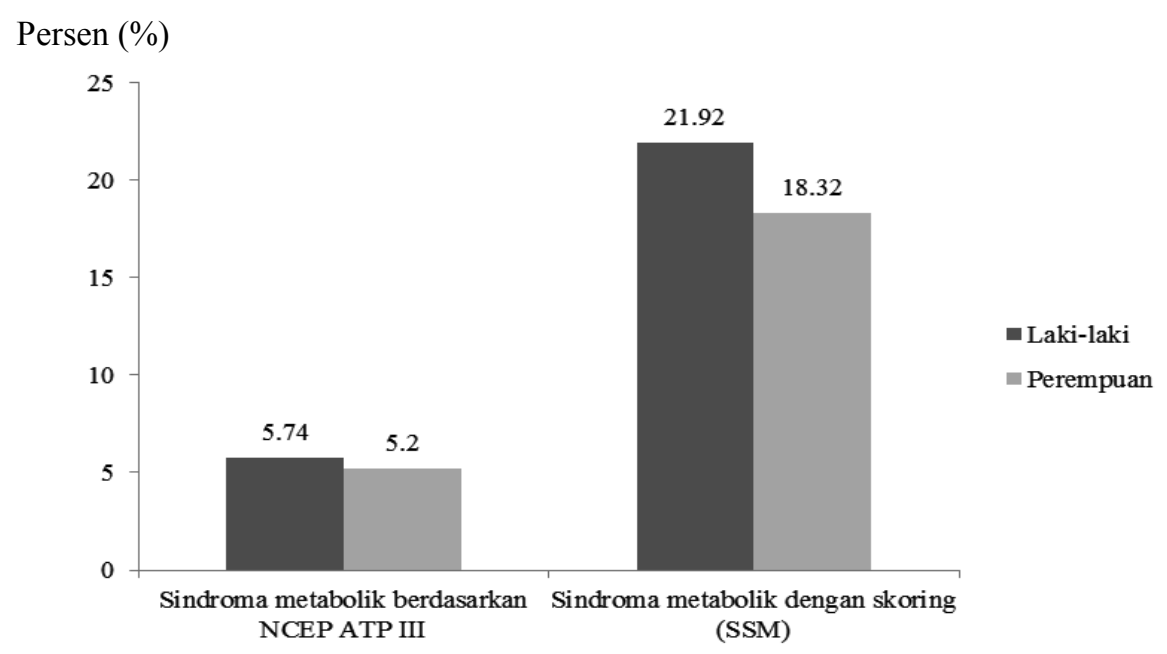

Gambar 6. Perbedaan prevalensi sindroma metabolik berdasarkan jenis kelamin

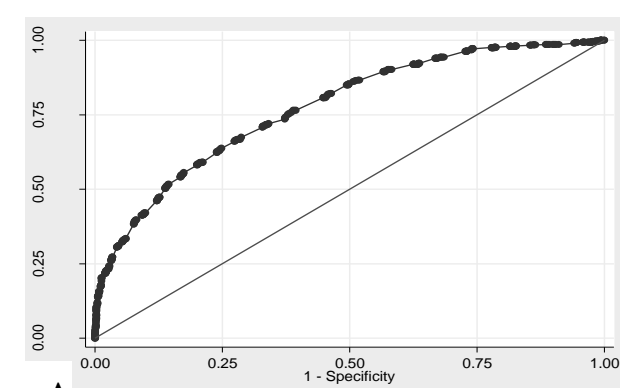

$\boldsymbol{\Delta}$

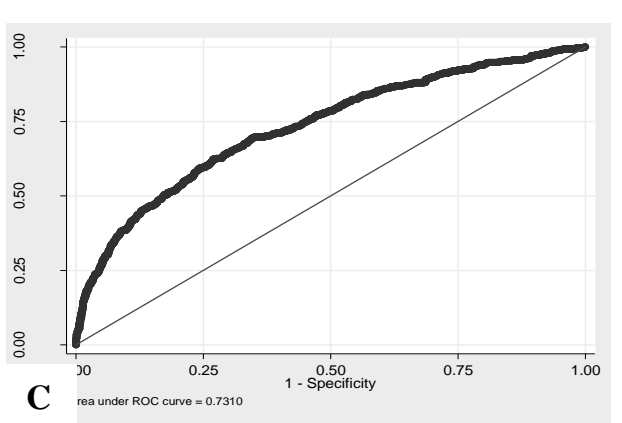

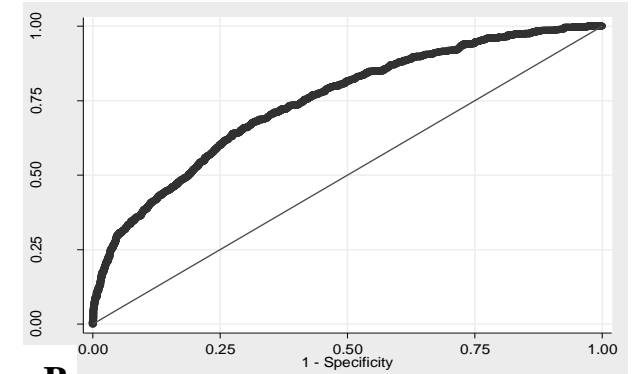

B

Keterangan:

A: AUC lingkar perut $=0,77$

B: $\mathrm{AUC} \mathrm{LP} / \mathrm{TB}=0,74$

C: AUC IMT $=0.73$

Gambar 7. Area Under Curve (AUC) parameter antropometri untuk diagnosis kategori SSM

Prevalensi sindroma metabolik baik berdasarkan kriteria NCEP ATP-III maupun metode skoring (SSM) menunjukkan bahwa remaja laki-laki memiliki prevalensi lebih tinggi untuk menderita sindroma metabolik daripada remaja perempuan (Gambar 6.). Prevalensi remaja lakilaki menderita sindroma metabolik berdasarkan kriteria NCEP ATP-III sebesar 5,74\% sedangkan prevalensi sindroma metabolik pada perempuan sebesar $5,2 \%$.

\section{Penilaian diagnostik parameter antropometri}

Parameter antropometri yang digunakan untuk mendiagnosis SSM adalah lingkar perut (LP), indeks massa tubuh (IMT), dan lingkar perut berdasarkan tinggi badan (LP/TB). Parameter antropometri yang paling baik untuk mendiagnosis sindroma metabolik (dengan nilai titik potong $\mathrm{SSM}=2,21$ ) adalah lingkar perut (titik 
Zahra Anggita Pratiwi, dkk: Penentuan titik potong skor sindroma metabolik remaja dan penilaian validitas diagnostik parameter antropometri

Tabel 4. Perbandingan uji diagnosis parameter antropometri terhadap kategori SSM

\begin{tabular}{lccccc}
\hline Parameter & Sensitivitas & Spesifisitas & AUC & 95\% CI & p \\
\hline Lingkar perut & $71 \%$ & $67 \%$ & 0,77 & $0,75-0,79$ & \\
LP/TB & $71 \%$ & $64 \%$ & 0,74 & $0,72-0,77$ & $<0,0001$ \\
IMT & $69 \%$ & $64 \%$ & 0,73 & $0,71-0,75$ & \\
\hline
\end{tabular}

potong $=71,50$; sensitivitas $=71 \%$; spesifisitas $=67 \%$ ). Hasil analisis menggunakan kurva ROC disajikan pada Gambar 7.

Lingkar perut merupakan parameter antropometri yang terbaik dalam mendeteksi SM karena memiliki nilai AUC paling besar dibandingkan dua parameter antropometri lainnya. Lingkar perut memiliki nilai sensitivitas dan spesifisitas tertinggi dibandingkan sensitivitas dan spesifisitas IMT dan LP/TB. Perbedaan AUC ketiga parameter antropometri tersebut bermakna secara statistik (Tabel 4.).

\section{BAHASAN}

Penelitian ini menemukan hampir sebagian subjek penelitian memiliki kadar kolesterol HDL yang rendah. Hal ini dapat disebabkan oleh adanya gangguan faktor-faktor biogenesis atau akibat kondisi subjek yang mengalami obesitas, merokok, aktivitas fisik yang rendah, dan kurang mengkonsumsi serat. Konsumsi serat yang tidak mencukupi kebutuhan dapat menyebabkan naiknya hidrolisis HDL dan meningkatkan sintesis trigliserida yang berdampak pada peningkatan kadar trigliserida (23).

Kriteria sindroma metabolik sampai saat ini masih belum mencapai kesepakatan, terutama pada anak-anak dan remaja. Terdapat perbedaan prevalensi sindroma metabolik dari berbagai hasil penelitian. Perbedaan tersebut selain disebabkan karena perbedaan demografis, dapat juga disebabkan oleh tidak konsistennya penggunaan kriteria dalam mendiagnosis sindroma metabolik. Penelitian ini menemukan prevalensi sindroma metabolik lebih tinggi bila menggunakan skoring daripada menggunakan kriteria NCEP ATP-III modifikasi. Sindroma metabolik lebih direkomendasikan menggunakan tipe kontinyu (skoring) dibandingkan dengan dikotomi atau biner ("ya" dan "tidak") (11).

Penelitian ini menemukan prevalensi sindroma metabolik lebih tinggi pada remaja laki-laki daripada remaja perempuan, baik menggunakan kriteria NCEP ATP-III maupun metode skoring. Penemuan ini sejalan dengan hasil penelitian yang menggunakan data Epidemiological Study on the Insulin Resistance Syndrome (D.E.S.I.R) pada kelompok dewasa usia 30-65 tahun, bahwa laki-laki (12,4\%) memiliki prevalensi lebih tinggi menderita sindroma metabolik (NCEP ATP-III) dibandingkan perempuan (7,2\%) (24). Remaja Algeria dan Korea juga memiliki prevalensi sindroma metabolik (NCEP ATP-III) lebih tinggi pada remaja laki-laki (4\% dan $15,4 \%)$ daripada remaja perempuan ( $2 \%$ dan $10 \%)(4,25)$. Namun, penelitian lain menunjukkan bahwa perempuan justru memiliki prevalensi lebih tinggi dibandingkan laki-laki. Prevalensi sindroma metabolik pada kelompok usia 45-54 tahun lebih tinggi pada perempuan (20,2\%) daripada laki-laki (14,2\%) (26).

Penelitian lain yang dilakukan di Brazil pada anakanak usia 8 dan 9 tahun menemukan sebanyak 24\% anak yang didiagnosis menderita sindroma metabolik dengan menggunakan metode skoring dan prevalensinya turun menjadi 8,9\% apabila menggunakan kriteria NCEP ATP-III modifikasi usia (13). Perbedaan yang besar antara prevalensi menggunakan metode skoring atau SSM dengan kriteria NCEP ATP-III disebabkan oleh pengukuran menggunakan SSM memiliki statistical power lebih besar daripada menggunakan klasifikasi dikotomi (11,13).

Pada penelitian ini, titik potong SSM dibedakan berdasarkan jenis kelamin karena pertimbangan perbedaan biologis dan fisiologis antara laki-laki dan perempuan. Titik potong SSM untuk remaja laki-laki lebih tinggi dibandingkan perempuan. Hasil analisis menunjukkan validitas diagnostik titik potong SSM, baik laki-laki maupun perempuan sama-sama memiliki nilai sensitivitas dan spesifisitas yang baik. Sementara itu, penelitian sebelumnya juga menemukan titik potong SSM lebih tinggi pada laki-laki dibandingkan perempuan. Hal ini dapat disebabkan adanya perbedaan 
karakteristik komposisi tubuh dan distribusi lemak. Laki-laki lebih cenderung mengalami obesitas sentral (berbentuk apel), sementara perempuan lebih cenderung mengalami obesitas dengan akumulasi lemak pada panggul (berbentuk pear). Hal tersebut terjadi sejak masa pubertas $(27,28)$.

Penentuan titik potong SSM yang dilakukan di Brazil menemukan titik potong optimal SSM sebesar 1,86 (sensitivitas $96,7 \%$; spesitifitas $82,7 \%$ ) dengan nilai AUC sebesar 0,96 (13). Sementara itu, penelitian serupa yang dilakukan di Iran menemukan titik potong optimal SSM pada anak-anak usia 8 dan 9 tahun sebesar $-1,15$ (sensitivitas $89 \%$; spesifisitas 88,2\%). Perbedaan titik potong pada penelitian yang dilakukan di Indonesia, Brazil, dan Iran dapat disebabkan oleh perbedaan usia, lingkungan, gaya hidup, dan ras (29).

Hasil penelitian ini menunjukkan lingkar perut adalah parameter antropometri yang paling baik dalam mendeteksi sindroma metabolik pada remaja karena memiliki nilai AUC tertinggi daripada IMT dan LP/TB. Sejalan dengan penelitian yang di lakukan di Iran, meskipun penelitian tersebut juga melibatkan subjek lansia (30). Berbeda dengan hasil penelitian lain yang justru menemukan lingkar perut tidak berhubungan dengan sindroma metabolik pada orang obesitas dan overweight. Parameter antropometri yang paling baik untuk memprediksi adiposit total pada anakanak dan remaja usia 8-18 tahun adalah rasio lingkar perut terhadap tinggi badan (LP/TB) (31). Rasio LP/TB mampu mengidentifikasi persen lemak tubuh pada usia muda di Australia (32).

Pengukuran lingkar perut memiliki keunggulan dari segi proses yang cepat, mudah, murah, dan lebih sensitif dan spesifik. Pengukuran lingkar perut dapat dijadikan sebagai alat deteksi dini sindroma metabolik yang non-invansive pada remaja. Program deteksi dini merupakan salah satu bentuk aktivitas dari promosi kesehatan yang berfokus pada pencegahan penyakit (ill health prevention). Deteksi dini termasuk dalam kategori secondary prevention yang bertujuan untuk mengurangi prevalensi penyakit dengan memperpendek durasi penyakit (33). Contoh, ketika seseorang diindikasikan berisiko sindroma metabolik dari pengukuran lingkar perut, maka dapat dilakukan penanganan dini seperti merubah gaya hidup secara bertahap sehingga diharapkan dapat mencegah perkembangan sindroma metabolik menjadi penyakit kardiovaskular atau diabetes melitus di masa depan.

\section{SIMPULAN DAN SARAN}

Sindroma metabolik tidak hanya terjadi pada usia dewasa, tetapi juga terjadi pada remaja. Penggunaan kriteria SSM dengan titik potong untuk laki-laki $=2,40$ (sensitivitas $=86 \%$, spesifisitas $=82 \%$ ) dan untuk perempuan $=2,02$ (sensitivitas $=84 \%$, spesifisitas $=85$ ) dapat digunakan untuk menentukan remaja yang berisiko sindroma metabolik. Lingkar perut memiliki validitas yang paling baik dan dapat digunakan untuk deteksi dini risiko sindroma metabolik pada remaja. Program deteksi dini pada remaja khususnya remaja awal dapat melibatkan pihak sekolah maupun dinas kesehatan setempat. Program deteksi dini dapat dilakukan sebagai sistem monitoring kesehatan yang dilakukan berkesinambungan dan terus menerus.

\section{UCAPAN TERIMAKASIH}

Peneliti mengucapkan terima kasih kepada Kepala Badan Penelitian dan Pengembangan RI yang telah memberikan izin menggunakan data survey Riskesdas 2013 sehingga penelitian ini dapat terlaksana.

\section{Pernyataan konflik kepentingan}

Tidak ada konflik kepentingan dalam penelitian ini.

\section{DAFTAR PUSTAKA}

1. Alberti KGMM, Zimmet P, Shaw J. The metabolic syndrome - a new worldwide definition. Lancet 2005;366(9491):1059-62.

2. Bray GA, Ryan D. Overweight and the metabolic syndrome: from bench to bedside. USA: Springer; 2006.

3. De Ferranti SD, Gauvreau K, Ludwig DS, Newburger JW, Rifai N. Inflammation and changes in metabolic syndrome abnormalities in US adolescents: findings from the 19881994 and 1999-2000 National Health and Nutrition Examination Surveys. Clin Chem 2006;52(7):1325-30.

4. You M-A, Son Y-J. Prevalence of metabolic syndrome and associated risk factors among Korean adolescents: analysis from the Korean national survey. Asia-Pacific J Public Heal 2012;24(3):464-71. 
5. Bantas K. Perbedaan gender pada kejadian sindrom metabolik pada penduduk perkotaan di Indonesia. Kesmas, Jurnal Kesehatan Masyarakat Nasional 2012;7(5):21926.

6. Wang J, Zhu Y, Cai L, Jing J, Chen Y, Mai J, et al. Metabolic syndrome and its associated early-life factors in children and adolescents: a cross-sectional study in Guangzhou, China. Public Health Nutr 2015;19(13):1-8.

7. Rini S. Sindrom metabolik. J Major 2015;4(4):88-93.

8. Kahn R, Buse J, Ferrannini E, Stern M. The metabolic syndrome: time for a critical appraisal. Diabetes Cares 2005;28(9):2289-304.

9. Okosun IS, Boltri JM, Lyn R, Davis-Smith M. Continuous metabolic syndrome risk score, body mass index percentile, and leisure time physical activity in American children. $\mathrm{J}$ Clin Hypertens (Greenwich) 2010;12(8):636-44.

10. Sastroasmoro S, Ismael S. Dasar-dasar metodologi penelitian klinis. edisi ke-4. Jakarta: Sagung seto; 2011.

11. Hosseini M, Sarrafzadegan N, Kelishadi R, Monajemi M, Asgary S, Vardanjani HM. Population-based metabolic syndrome risk score and its determinants: The Isfahan Healthy Heart Program. J Res Med Sci 2014;9(12):116774.

12. Pandit D, Chiplonkar S, Khadilkar A, Kinare A, Khadilkar V. Efficacy of a continuous metabolic syndrome score in Indian children for detecting subclinical atherosclerotic risk. Int J Obes (Lond) 2011;35(10):1318-24.

13. Villa JKD, e Silva AR, Santos TSS, Ribeiro AQ, Sant'Ana LFDR. Metabolic syndrome risk assessment in children: use of a single score. Rev Paul Pediatr 2015;33(2):18793.

14. Hsiung D-Y, Liu C-W, Cheng P-C, Ma W-F. Using non-invasive assessment methods to predict the risk of metabolic syndrome. Appl Nurs Res 2014;28(2):72-7.

15. Kamso S, Dharmayati P, Lubis U, Juwita R, Kurnia Y, Besral R. Prevalensi dan determinan sindrom metabolik pada kelompok eksekutif di Jakarta dan sekitarnya. Kesmas, Jurnal Kesehatan Masyarakat Nasional 2011;6(2):85-90.

16. Kementerian Kesehatan. Riset Kesehatan Dasar 2013. Jakarta; Kemenkes RI; 2013.

17. Kassi E, Pervanidou P, Kaltsas G, Chrousos G. Metabolic syndrome: definitions and controversies. BMC Med 2011;9(1):48.

18. Moy FM, Bulgiba A. The modified NCEP ATP III criteria maybe better than the IDF criteria in diagnosing metabolic syndrome among Malays in Kuala Lumpur. BMC Public Health 2010;10(678):2-7.

19. Soewondo P, Purnamasari D, Oemardi M, Waspadji S, Soegondo S. Prevalence of metabolic syndrome using NCEP/ATP III criteria in Jakarta, Indonesia: the Jakarta primary non-communicable disease risk factors surveillance 2006. Acta Med Indones 2010;42(4):199203.

20. Eisenmann JC. On the use of a continuous metabolic syndrome score in pediatric research. Cardiovasc Diabetol 2008;7:17.

21. Eisenmann JC, Laurson KR, DuBose KD, Smith BK, Donnelly JE. Construct validity of a continuous metabolic syndrome score in children. Diabetol Metab Syndr 2010;2:8.

22. Stabelini Neto A, de Campos W, Dos Santos GC, Mazzardo Junior O. Metabolic syndrome risk score and time expended in moderate to vigorous physical activity in adolescents. BMC Pediatr 2014;14:42.

23. Velásquez-villa M, Gómez-ocampo L, Bermúdez-cardona J. Abdominal obesity and low physical activity are associated with insulin resistance in overweight adolescents : a crosssectional study. BMC Pediatr 2014;14(52):1-9.

24. Hillier TA, Rousseau A, Lange C, Lépinay P, Cailleau M, Balkau B, et al. Practical way to assess metabolic syndrome using a continuous score obtained from principal components analysis. Diabetologia 2006;49(7):1528-35.

25. Benmohammed K, Valensi P, Benlatreche M, Nguyen MT, Benmohammed F, Pariès J, et al. Anthropometric markers for detection of the metabolic syndrome in adolescents. Diabetes Metab 2015;41(2):138-44.

26. Sihombing M, Tjandrarini DH. Faktor risiko sindrom metabolik pada orang dewasa di Kota Bogor. Penel Gizi dan Makanan 2015;38(1):21-30.

27. Kelsey MM, Zeitler PS. Insulin resistance of puberty. Curr Diab Rep 2016;16(7):64.

28. Neinstein LS. Handbook of adolescent health care. United States: Lippincott Williams \& Wilkins; 2009.

29. Susilawati MD, Bantas K, Jahari AB. Nilai batas dan indikator obesitas terhadap terjadinya diabetes mellitus tipe 2. Penel Gizi Makanan 2014;2(1):11-20.

30. Gharipour M, Sadeghi M, Dianatkhah M, Bidmeshgi S, Ahmadi A, Tahri M, et al. The cut-off values of anthropometric indices for identifying subjects at risk for metabolic syndrome in Iranian elderly men. J Obes 2014;2014.

31. Brambilla P, Bedogni G, Heo M, Pietrobelli A. Waist circumference-to-height ratio predicts adiposity better than body mass index in children and adolescents. Int $\mathrm{J}$ Obes 2013;37(7):943-6.

32. Nambiar S, Hughes I, Davies PS. Developing waistto-height ratio cut-offs to define overweight and obesity in children and adolescents. Public Health Nutr 2010;13(10):1566-74.

33. Carr SNUTP-M. An introduction to public health and epidemiology. second edition. New York: Open University Press; 2007. 